Çukurova Üniversitesi Mühendislik Mimarlık Fakültesi Dergisi, 35(4), ss. 897-912, Aralık 2020

\title{
Afyonkarahisar-Dinar Dombayova Kömür Sahasının Tektono- Stratigrafik İncelemesi, Saha İçindeki Linyit Depolarının Jeolojik Gelişimi ve Rezerv Olanakları
}

\author{
Kemal PEKKIYICI ${ }^{* 1}$, Ulvi Can ÜNLÜGENÇ ${ }^{2}$, Hatice KARAKILÇIK ${ }^{2}$ \\ ${ }^{1}$ EÜAŞ., Karapınar Maden Etüt Tesis Müdürlüğü, Konya \\ ${ }^{2}$ Çukurova Üniversitesi, Mühendislik Fakültesi, Jeoloji Mühendisliği Bölümü, Adana
}

Geliş tarihi: 19.10.2020 Kabul tarihi: 30.12 .2020

$\ddot{\mathbf{O z}}$

Çalışma alanı, Afyonkarahisar iline bağlı Dinar ilçesinin yaklaşık $10 \mathrm{~km}$ kuzeydoğusunda bulunan ve Göller bölgesinin oluşumunu da kontrol eden horst-graben sistemi içerisinde yer almaktadır. Çalışılan alan; horst-graben sistemi ve normal-verev atımlı faylar tarafından şekillendirilmiştir. Çalışmaların yürütüldüğü Dombayova grabeni yaklaşık olarak 5 ile $7 \mathrm{~km}$ genişliğinde, $20 \mathrm{~km}$ uzunluğunda bir çöküntü bölgesidir. Dombayova grabeni; kenarlarda alüvyon yelpazeleri ve yamaç molozları gibi genellikle orta-iri taneli birimlerden, orta kısımlarda ise kenar birimlerle yanal-düşey geçişli, kiltaşı, silttaşı, kumtaşı, çamurtaşı ve çok pekişmemiş kırıntılı birimlerden oluşmaktadır. Çalışma alanındaki aktif tektonizma nedeniyle sahanın özellikle doğu kenarlarındaki birimlerde gözle görülebilen eğimlenmeler dikkat çekmektedir. Ayrıca bu durum, sondajlardan alınan karotlarda da gözlendiği üzere bazı alanlarda yer yer sıkı kıvrımlanmalara sebebiyet vermiştir. Bu süreç sahada normal faylanmaların oluşumu ile birlikte verev atımlı faylanmaların gelişimini de sağlamıştır. Dombayova grabeni; batı ve doğu kenarlarından, havza merkezine doğru eğimli olan normal ve verev atıml faylarla temsil edilmektedir. Sondaj çalışmalarında gözlemlendiği üzere, havzadaki faylar mevcut birimlerin çok kısa mesafelerde farklı seviyelerde oluşmasına neden olmuştur. Benzer ötelenmelere linyit damarlarında da gözlenmiştir. $\mathrm{Bu}$ nedenle kömür korelasyonu ve damar modellenmesinde zorluklarla karşılaşılmıştır. Söz konusu grabende yapılan sondaj çalışmaları ile yaklaşık olarak 1,525 milyar ton ( \pm 100 milyon ton) rezerve sahip Geç Pliyosen-Kuvarterner yaşlı çökellerin altında oluşmuş, Miyosen-Pliyosen yaşlı linyitlerin varlığ tespit edilmiştir. Sahadaki linyitlerin kalınlıkları havza kenarlarında birkaç cm'den başlayıp, havza merkezine doğru yer yer yüzlerce metre kalınlığa ulaşmaktadır. Yapılan laboratuvar analizleri neticesinde bu linyitlerin ortalama olarak $1783 \mathrm{kcal} / \mathrm{kg}$ alt 1sıl değere, \%40,57 nem, \%18,97 kül, \%27,65 uçucu madde, \%12,81 sabit karbon, \%0,73 külde kükürt ve \%1,25 toplam kükürt değerlerine sahip olduğu tespit edilmiştir.

Anahtar Kelimeler: Dombayova grabeni, Normal ve verev atımlı faylanma, Linyit

\footnotetext{
* Sorumlu yazar (Corresponding author): Kemal PEKKIYICI, kmlcm_01@hotmail.com
} 


\title{
Tectono-Stratigraphic Investigation of Afyonkarahisar-Dinar-Dombayova Coalsite and Geological Development and Reserve Potential of Lignite Deposits in the Area
}

\begin{abstract}
The study area is located $10 \mathrm{~km}$ to the northeast of Dinar district of Afyonkarahisar province within the horst-graben system that also controls the formation of the Lakes region. The studied horst-graben system was formed by oblique slip faults along with normal faulting. The Dombayova graben is a depression region of approximately 5 to $7 \mathrm{~km}$ in width and $20 \mathrm{~km}$ in length. Dombayova graben consists of generally medium-grained units such as alluvial fans and slope debris at the edges of the basin, and claystone, siltstone, sandstone, mudstone and unconsolidated clastic units at the center of the basin that has lateral and vertical transition. Due to the active tectonism in the study area, visible inclinations in the units especially in the eastern side of the area are remarkable. In addition, as observed in the cores taken from the boreholes, tight folding formed in some areas. This tectonic process, along with the formation of normal faulting in the field has led to the development of oblique slip faulting. Dombayova graben, is represented by normal and oblique slip faults sloping from the western and eastern edges towards the basin center. As observed in the drilling studies, faults in the basin caused the existing units to form at different levels over very short distances. Similar displacements have also been observed in the lignite veins. The drilling activities carried out in the graben, the presence of Miocene-Pliocene aged lignites formed under the Late Pliocene-Quarternary sediments with a reserve of approximately 1.525 billion tons ( \pm 100 million tons) were determined. The thickness of the lignites in the field starts from a few $\mathrm{cm}$ on the edges of the basin and reaches to the basin center from hundreds of meters in some places. As a result of the laboratory analyzes, these lignites have an average of $1783 \mathrm{kcal} / \mathrm{kg}$ Lower thermal value, $40.57 \%$ moisture, $18.97 \%$ ash, $27.65 \%$ volatile matter, $12.81 \%$ constant carbon, $0.73 \%$ sulfur in ash, $1.25 \%$ total sulfur values.
\end{abstract}

Key Words: Dombayova graben, Normal and oblique-slip faulting, Lignite

\section{GíRiș}

Yurdumuzun enerji ihtiyacının büyük bir bölümü; doğalgaz, petrol gibi yer altı ve yer üstü fosil yakıt kaynaklarından elde edilen hammaddelerin çeşitli işletim tesislerinde kullanılması suretiyle karşılanmaktadır. Ülkemiz doğalgaz ve petrol gibi fosil yakıt kaynakları bakımından fakir sayllabilecek nitelikte bir ülkedir. $\mathrm{Bu}$ enerji kaynaklarına alternatif olarak kullanılabilecek; Dinar, Karapınar-Ayranc1, Alpu, Çerkezköy, Malkara vb. gibi yurdumuzun çeşitli bölgelerinde oluşmuş linyit yatakları bulunmaktadır [1]. Mevcut yataklardaki linyitlerin bir kısmı, nem ve kül oranı açısından yüksek olmasına rağmen bu linyitlerin kalorifik değerleri ise yaklaşık olarak $1000-2000 \mathrm{kcal} / \mathrm{kg}$ aralığında olduğundan dolayı bu linyitler genel olarak düşük kalorili olarak nitelendirilebilir [2]. Buna rağmen, rezerv miktarı ve sahaların yurt genelindeki dağılımı göz önüne alındığında; linyit yataklarının enerji üretiminde hammadde olarak kullanılması da cazip hale gelmektedir. Her geçen gün artan elektrik ihtiyacının karşılanması amacıyla gerek ülkemizde gerekse dünyanın birçok ülkesinde linyitlerin enerji üretimindeki önemi giderek artmaktadır. $\mathrm{Bu}$ çerçevede yurdumuzun İç Batı Anadolu bölgesinde yer alan Dombayova yöresinde oluşmuş kömür sahası ülke ekonomisi açısından önem arz etmektedir (Şekil 1). Genç linyit depolarının oluşum gösterdiği bu sahada yapılan ARGE çalışmaları neticesinde, ciddi bir rezerv potansiyeline sahip linyitlerin olduğu tespit edilmiştir. Yapılan jeolojik, sondaj ve sismik araştırmalar sonucunda sahanın, normal fayların kontrolünde bir dizi tektonik etkiler sonucunda kuzeybatı-güneydoğu uzanımlı bir şekilde oluştuğu tespit edilmiştir. Çalışma alanını şekillendiren ana faylar; Çobansaray, Akçaköy fay setleri ve Eldere faylarıdır [3]. Bunun yanı sıra 
çalışma sahasında bahsi geçen ana faylar dışında sismik çalışmalar ile tespit edilmiş, doğu-batı ve kuzey-güney uzanımlı ikincil faylar da bulunmaktadır. Bu kapsamda, kömür havzasının jeolojik ve jeoteknik özelliklerini tespit etmek amacıyla toplam ilerleme miktarı yaklaşık 140 bin metre olan 255 adet sondaj yapılmıştır. Sondajlardan elde edilen karotlar üzerinde yapilan laboratuvar analizleri ve sahada yapılan sismik çalışmalar neticesinde elde edilen bilgiler ile kömürlü seviyeler belirlenerek sahadaki mevcut fayların havzanın gelişimi ile ilişkisi ve rezerv durumu detaylı olarak araştırılmıştır.

\section{MATERYAL VE METOT}

\subsection{Materyal}

Çalışmalar; Afyonkarahisar ili, Dinar ilçesi, Uluköy, Akçaköy, Akgün, Dombay, Yeşilyurt, Burunkaya, Karataş, Cumhuriyet köyleri sınırları içerisinde, 1/25000 ölçekli jeoloji haritasının Afyonkarahisar L24c1-L24c4-L24d2-L24d3 paftalarında gerçekleştirilmiştir. Genel olarak çalışmalar; rezerv geliştirme amaçlı sondaj çalışmaları, kuyu jeofizik çalışmaları kapsamında gamma-ray, nötron ve density logları, yüzey jeofizik çalışmaları kapsamında ise sismik yansıma çalışmaları şeklinde yürütülmüştür. Bununla beraber kömür korelasyonu, kömürlerin üç boyutlu modellemesi ve rezerv hesaplama gibi özelliklerin ortaya konmasına yönelik Mapinfo-Discover ve Netpromine programlarından yararlanılarak mevcut havza modellemeleri yapılmıştır [4].

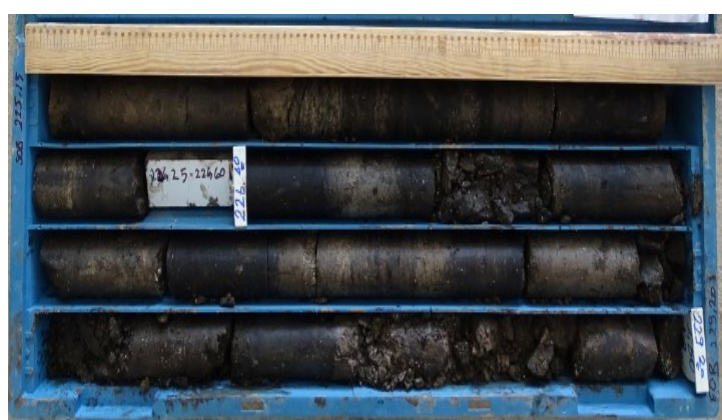

Şekil 1. Çalışma alanında yapılan sondajlara ait karot numunelerinin genel görünümü $(225,15-229,20 \mathrm{~m})$

\subsection{Metod}

Çalışmanın amacına yönelik incelemeler; saha öncesi, saha, laboratuvar ve büro çalışmaları olmak üzere 4 aşamada gerçekleştirilmiştir.

\subsubsection{Saha Öncesi Büro Çalıșmaları}

Saha öncesi büro çalışmaları kapsamında; daha önceden sahada yapılmış olan çalışmalar incelenmiş, bölge ve çevresiyle ilgili literatür taraması yapılmıştır. Bahse konu çalışma alanında 2008-2011 yılları arasında 120 adet sondaj çalışması yapılmış olup, burada sağlanan bazı veriler bu çalışmada da değerlendirilmiştir [5].

\subsubsection{Saha Çalışmaları}

Saha çalışmaları kapsamında; linyit mevcudiyetinin detaylı olarak ele alınması, bu linyitlerden alınan örneklerin analiz değerlerinin araştırılması ve ileride kurulması planlanan termik santral için çalışma alanının mühendislik özelliklerinin ortaya konulmasına yönelik, 2017 ve 2018 yıllarında toplam 255 adet sondaj yapılmıştır [6].

$\mathrm{Bu}$ sondajlar ile alınan karotlardan, linyitli ve karbonlu olduğu düşünülen seviyelerden loglama ve örnekleme yapılmak suretiyle numuneler alınmış ve analiz değerleri belirlenmek üzere gerekli laboratuvar çalışmaları yapılmıştır. Bunun yanı sıra sondajların bitmesinin hemen ardından kuyularda jeofizik çalışmalar kapsamında; kuyu jeofiziği olarak gamma-ray, nötron ve density log çalışmaları yapılmış, yüzey jeofiziği çalışmaları kapsamında ise sismik yansıma modeli çalışması yapılmıştır. Böylece sahanın farklı bölgelerinde, yaklaşık 14 metre'den başlayıp 977 metreye kadar gözlenen kömürlü seviyeler belirlenmiştir. Ayrıca yapılan sismik çalışmalar ile toplam uzunluğu $263.426 \mathrm{~km}$ olan 44 adet yüksek ayrımlı sismik hattan veri toplanarak veri işlem ve yorumlama çalışması yapılmıştır. Dombayova grabenini oluşturan kuzey-güney gidişli verev atımlı ana faylardan Akçaköy fayı ve graben içindeki diğer ikincil faylar tespit edilmiştir [7]. 


\subsubsection{Laboratuvar Çalışmaları}

Kömür numuneleri, görsel tanımlama çalışmalarından sonra boyuna ikiye bölünerek analizleri yapılmak üzere laboratuvarlara yollanmıştır. Numuneler ögütülüp toz haline getirildikten sonra laboratuvarlarda belirli sıcaklık derecelerinde ve belirli zaman aralıklarında; kısa analizler (nem, kül, uçucu madde, sabit karbon), tam analizler (karbon, hidrojen, oksijen, azot ve kükürt) ve kalorifik değerlerini tespit amaçlı analiz çalışmaları gerçekleştirilmiştir.

\subsubsection{Büro Çalışmaları}

Büro çalışmaları kapsamında saha çalışmalarından elde edilen veriler ve ölçümler kullanılarak gerekli harita çizimleri, grafik ve diyagramlar yardımı ile kömür havzası detaylı bir şekilde değerlendirilmiştir.

\section{PROJE ALANININ JEOLOJISİ}

Türkiye, Alp-Himalaya dağ kuşağ1 içerisinde yer almaktadır [8]. Anadolu levhası güneyde kuzeykuzeybatı yönlü hareket eden Arap ve Afrika levhaları ile kuzeyde Avrupa levhası arasında yer almaktadır Anadolu levhasının, diğer levhalarla olan sinır zonlarını; Kuzey Anadolu Fay Hattı, Doğu Anadolu Fay Hattı ve Bitlis Bindirme Kuşağı oluşturmaktadır [9-11]. Anadolu levhası kuzey yönlü sıkıştırma ile batıya doğru kaymaya zorlanmaktadır [12,13]. Batıya doğru kaymaya zorlanan Anadolu levhası, Ege levhası tarafindan durdurulmaya çalışılmış; böylece bölgede K-G yönlü bir genişleme meydana gelmiş ve bu durum Ege grabenlerinin oluşumuna sebebiyet vermiştir [8,14]. Batı Anadolu bölgesindeki horst-graben sistemlerinin oluşumunu sağlayan bu tektonik hareketler, Dinar ve Dombayova grabenlerinin gelişiminde etkin rol oynamıştır (Şekil 2). Türkiye'nin güneybatı ve çevresinin tektonik tarihçesi üçe ayrılmıştır. Bunlar eski, yeni ve geçiş tektonik dönemleridir. Geçiş dönemi, Alp orojenezinin olduğu bölgelerde genel olarak gözlemlendiği üzere sulu karasal istiflerle temsil edilmektedir. Geç Miyosen-Erken Pliyosen'de başlamış olan yeni tektonik dönem ise gerilme tektoniği ile gelişmiş karasal tortullaşma, bununla yaşıt kıta içi volkanizma ve blok faylanma ile karakterize edilmektedir [15].

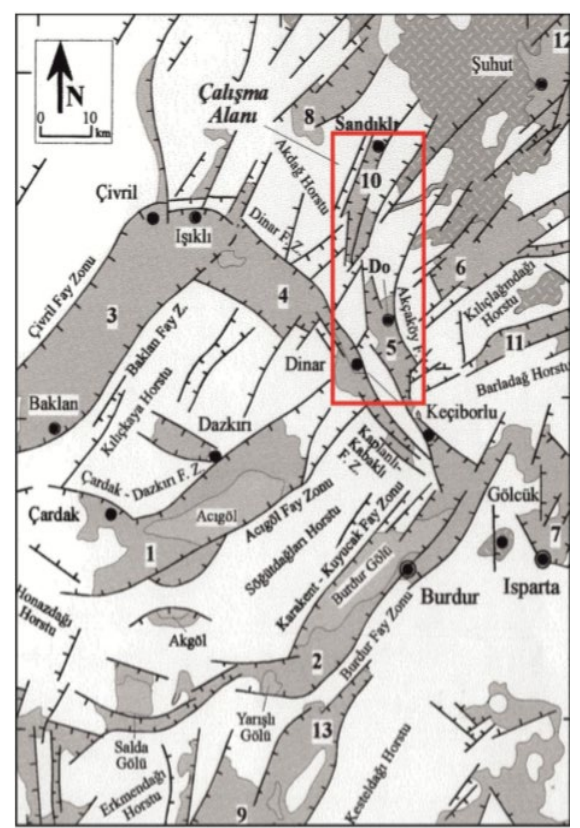

Şekil 2. Batı Türkiye ve çevresindeki önemli neotektonik yapılar ile 5 no’lu bölge olan çalışma alanının konumu [3] 
Yukarıda da bahsedildiği üzere Dombayova ve yakın çevresini oluşturan formasyonlar ise eski dönem kaya toplulukları (Paleotektonik) ve yeni tektonik dönem kaya toplulukları (Neotektonik) olmak üzere iki ana grup kaya topluluğu olarak tanımlanmıştır. Eski dönem kaya topluluklarını, Paleozoyik yaşlı metamorfitler ve bunları uyumsuz olarak üzerleyen Triyas-Lütesiyen yaşlı otokton istifler olup; her iki birimi de tektonik dokanakla üzerleyen 'İç Toros Ofiyolitli Melanj Nap1' ve tüm bunları önceki birimleri açılı uyumsuzlukla örten Erken-Orta Oligosen yaşlı sulu karasal istiflerle (denizel-karasal çakıltaşı- kumtaşı ardalanması), üzerinde Miyosen-Orta Pliyosen yaşlı kömür içerikli akarsu ve göl kökenli sedimanter örtü oluşturmaktadır. $\mathrm{Bu}$ birimler birden fazla evrede tektonik deformasyonlara maruz kalmışladır. Yeni tektonik dönem kaya toplulukları; pekişmemiş ve deformasyona uğramamış yatay/yataya yakın konumlu, Geç Pliyosen-Kuvarterner yaşlı kaya ve sedimanlardan oluşmaktadır. Havzanın tamamında yüzeyleyen 'yeni tektonik dönem birimleri', aktif faylanma nedeniyle 'eski tektonik dönem birimleri' ile genelde faylı dokanak ilişkisine sahiptir (Şekil 3) [15].

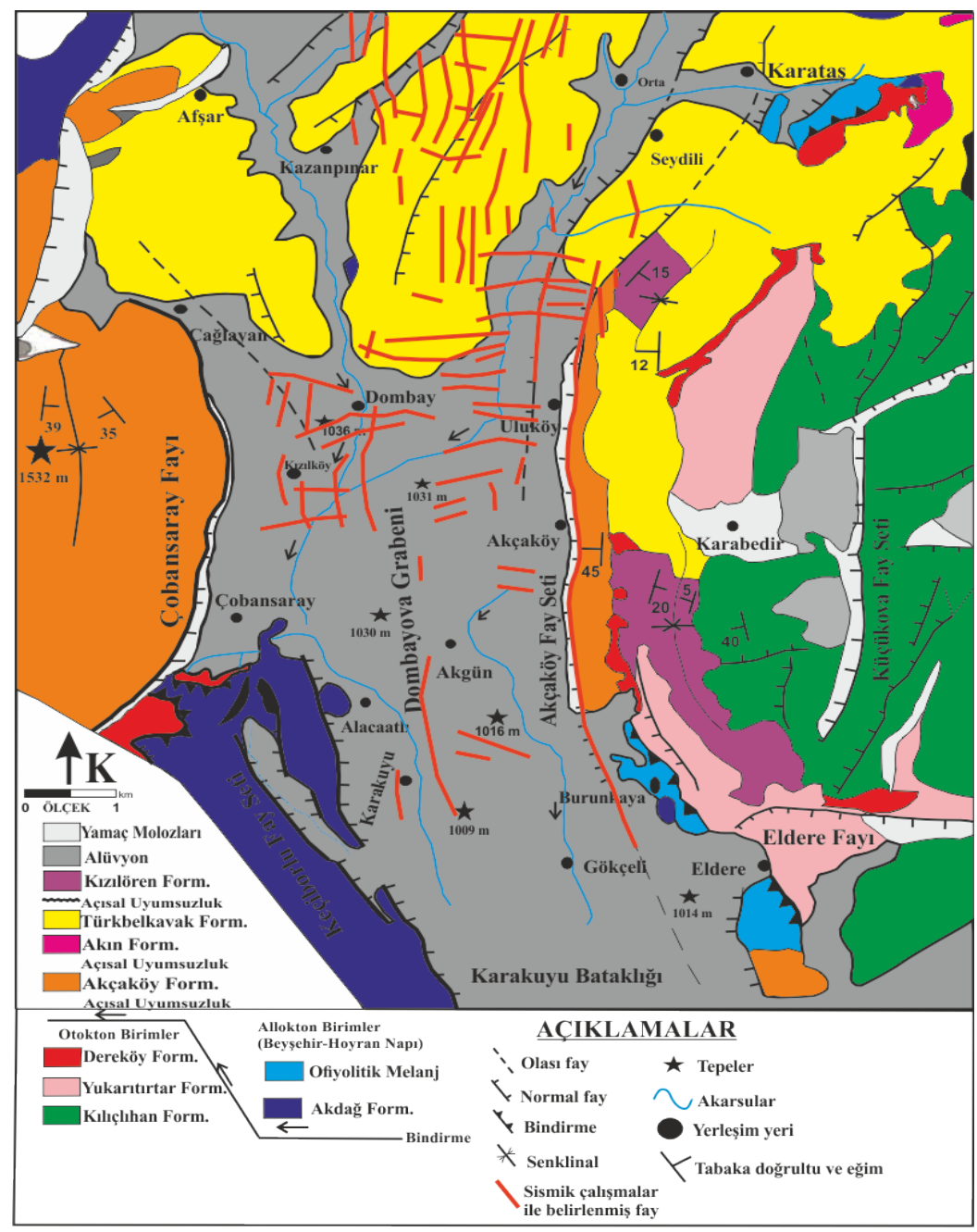

Şekil 3. Dombayova ve çevresinin Türkiye Petrolleri tarafından yapılmış olan sismik hatlardan belirlenen fayları (harita üzerindeki kırmızı hatlar) gösterir jeoloji haritası ([3,7]'den değiştirilerek) 
Afyonkarahisar-Dinar Dombayova Kömür Sahasının Tektono-stratigrafik Olarak İncelenmesi, Saha İçindeki Linyit Depolarının Jeolojik Gelişimi ve Rezerv Olanakları

Çalışma alanında Paleotektonik birimleri; allokton birimler olan Akdağ formasyonu ve İç Toros Ofiyolitik Melanj birimleri oluşturmakta olup otokton birimler ise Kilıçlıhan, Yukarıtırtar ve Dereköy formasyonları ile temsil edilmektedir. Paleotektonik özellikteki diğer formasyonlar yaşlı birimlerden genç birimlere doğru; Akçaköy, Akın ve Türkbelkavak formasyonlarıdır. Neotektonik birimleri ise; Pliyosen-Holosen yaşlı Kızılören formasyonu, alüvyal yelpaze malzemeleri ve graben sedimanları oluşturmaktadır (Şekil 4) [3]. Bir diğer araştırmacı tarafından çalışma alanı ve çevresi ise yaşlı birimlerden genç birimlere doğru; kömürlü zonları da içeren Güzelyayla, Kumalar, Kepeztepe ve Karataş formasyonları olarak tanımlanmıştır (Şekil 4) [16].

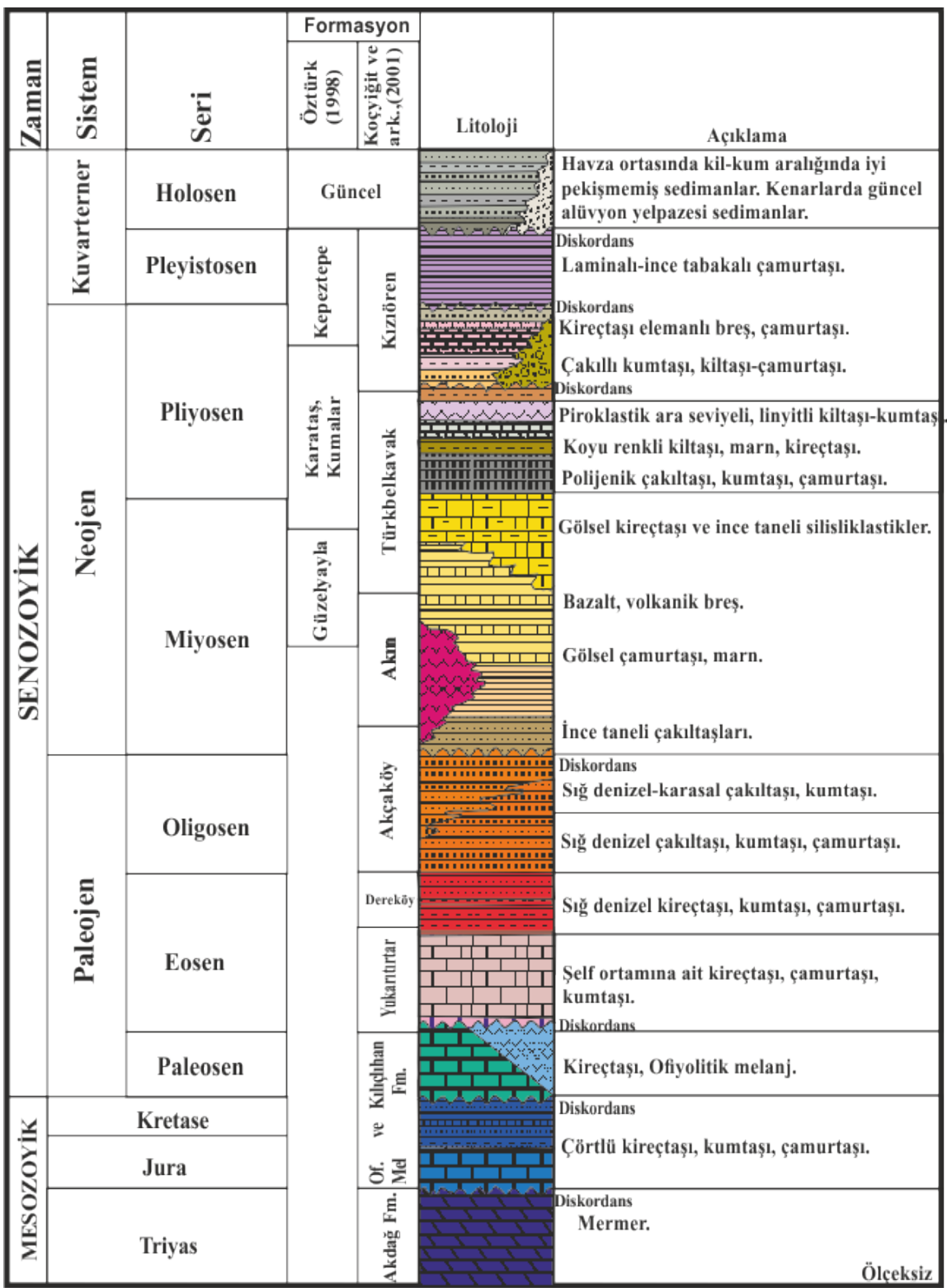

Şekil 4. İnceleme alanı ve civarının genelleştirilmiş stratigrafik kesiti ([3]'den değiştirilerek) 


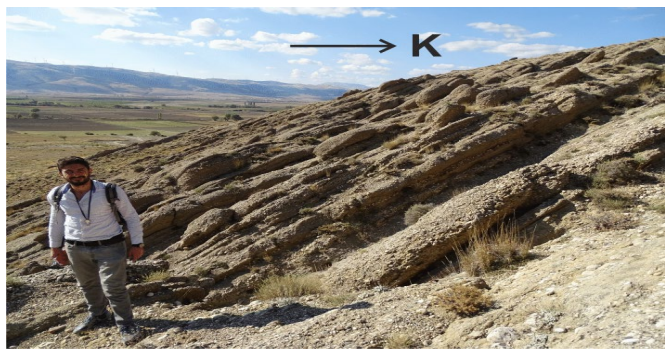

(a)

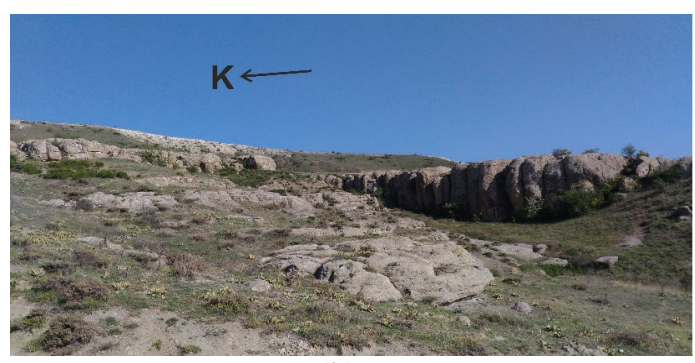

(b)

Şekil 5. a) Akçaköy’ün yaklaşık $1,5 \mathrm{~km}$ güneydoğusunda bulunan Oligosen yaşlı konglomeralardan oluşan Akçaköy formasyonuna ait görünüm b) Karataş köyünün yaklaşık 1,5 km doğusunda bulunan Miyosen yaşlı tüf ve ignimbiritlerden oluşan Akın formasyonuna ait görünüm

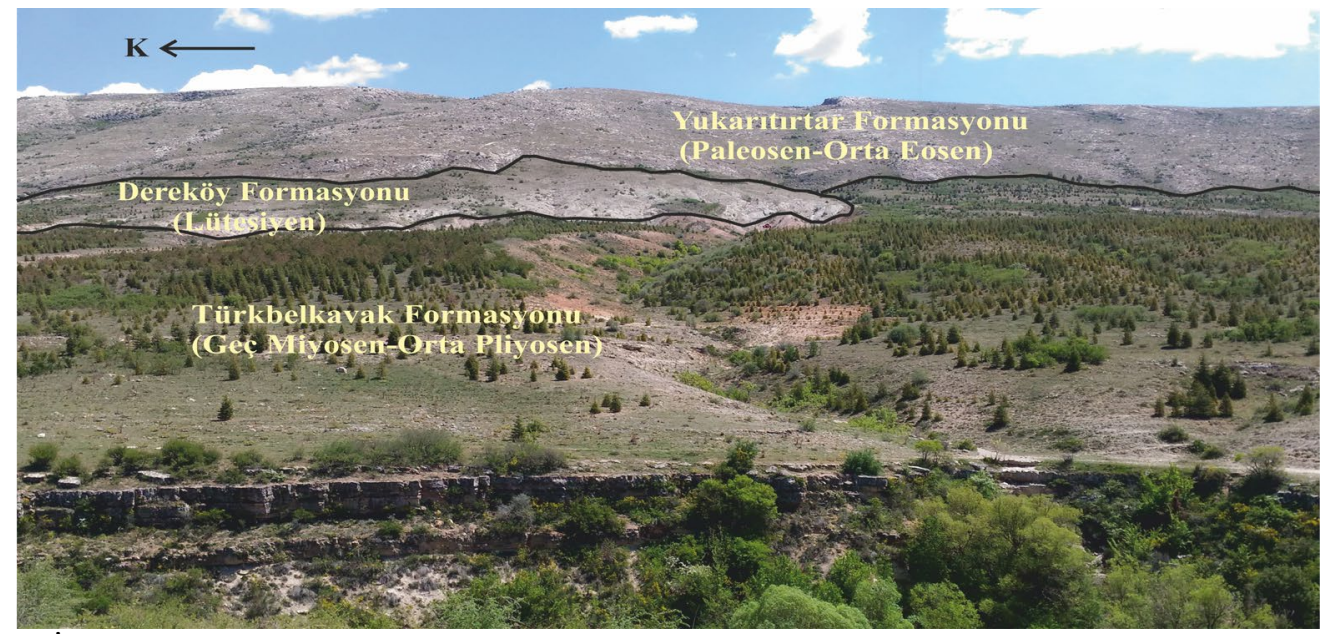

Şekil 6. İnceleme alanında, Uluköy’ün yaklaşık $1,5 \mathrm{~km}$ doğu kesimlerindeki Lütesiyen yaşlı Dereköy formasyonunun diğer birimlerle olan dokanak ilişkisi

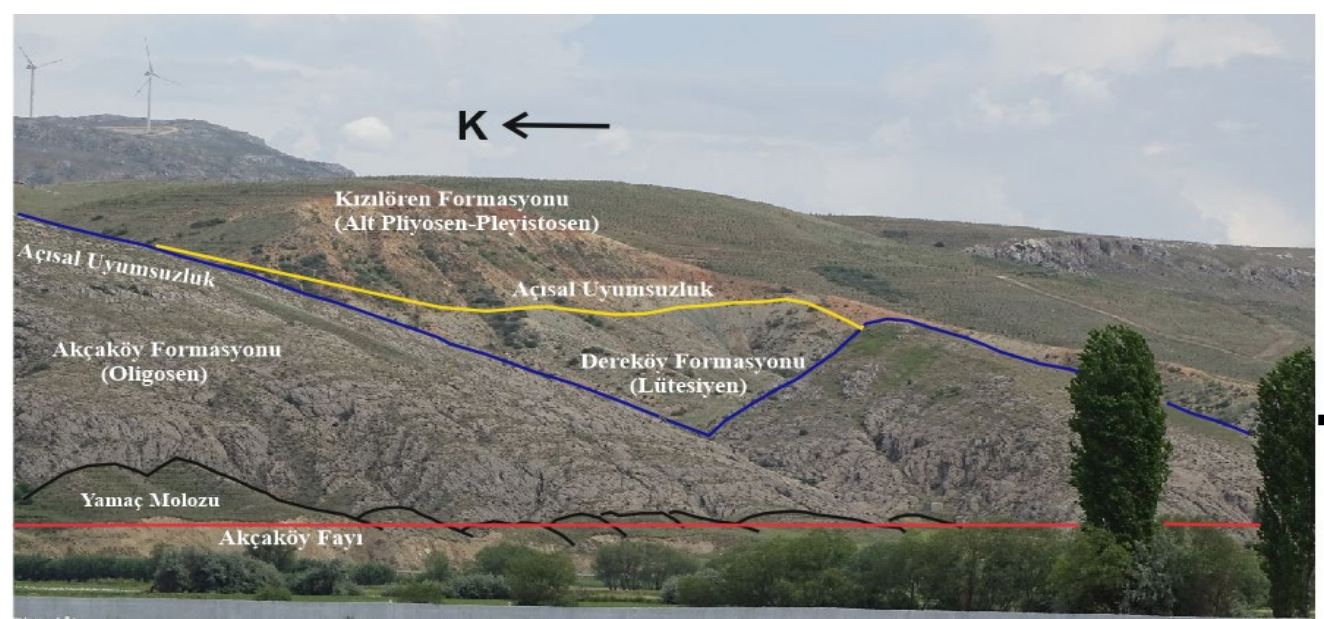

Şekil 7. Dombayova grabeninde, Akçaköy’ün yaklaşık $1 \mathrm{~km}$ güneydoğu yamacında aktif faylarla (Akçaköy fayı) ötelenmiş alüvyal yelpaze oluşumlarından genel görünüm 


\subsection{Yapısal Jeoloji}

Dombayova grabeni; bölgesel ölçekte Güneybatı Türkiye'de genişlemeli neotektonik bölgesinde, yerel ölçekte ise Göller bölgesinde yer alan horstgraben sistemi içerisinde yer almaktadır.

Dombayova grabenin doğu ve batı kenar kısımları, uzunlukları 7 ve $20 \mathrm{~km}$ aralıklarında değişen, birbirine paralel-yarı paralel, yaklaşık kuzey-güney uzanımlı, kenar kısımlarından grabene doğru eğimli ve basamak türü normal faylardan oluşmuş fay ve fay setleri tarafindan denetlenir. Dombayova havzasının şekillenmesini sağlayan bu fay ve fay setleri; Çobansaray fayı, Keçiborlu fay seti, Akçaköy fay seti, Küçükova fay seti ve Eldere faylarıdır (Şekil 9). Bu fayların, yapılan kinematik analizler neticesinde hem sol ve sağ doğrultu atımlı hem de normal fay özelliği gösteren oblik karakterli faylar olduğu tespit edilmiştir [3]. Bahse konu faylar; Dombayova grabeninin gelişimini etkilemekle kalmamış, aynı zamanda havza içerisinde bulunan linyitli seviyelerde ötelenmelere de neden olmuştur. Yaklaşık $3 \mathrm{~km}$ uzunluğunda, bat1-doğu uzanımlı jeolojik enine kesitte de görüldüğü üzere, linyitli birimler havzanın batı kısımlarından merkezine doğru kalınlaşmış ve buralarda yapılan sondajlarda da tespit edildiği üzere yaklaşık 165 metre seviyelerinde başlayıp 615 metre seviyelerine kadar gözlenmiştir. Havzanın orta kısımlarında yer alan A-152 no'lu sondajda kömür kalınlığının yaklaşık 52 metre olduğu tespit edilmiştir. Sismik çalışmalar ile desteklenmiş jeolojik enine kesitte, siyah renkle gösterilen kömürlü birimleri içeren formasyonda, ana faylar ile birlikte, havza içerisinde sondaj çalışmalarıyla da tespit edilmiş (A-153, A-154 vb.) doğu-batı ve kuzey-güney yönlü birçok ikincil fay da tespit edilmiştir (Şekil 8) [4].

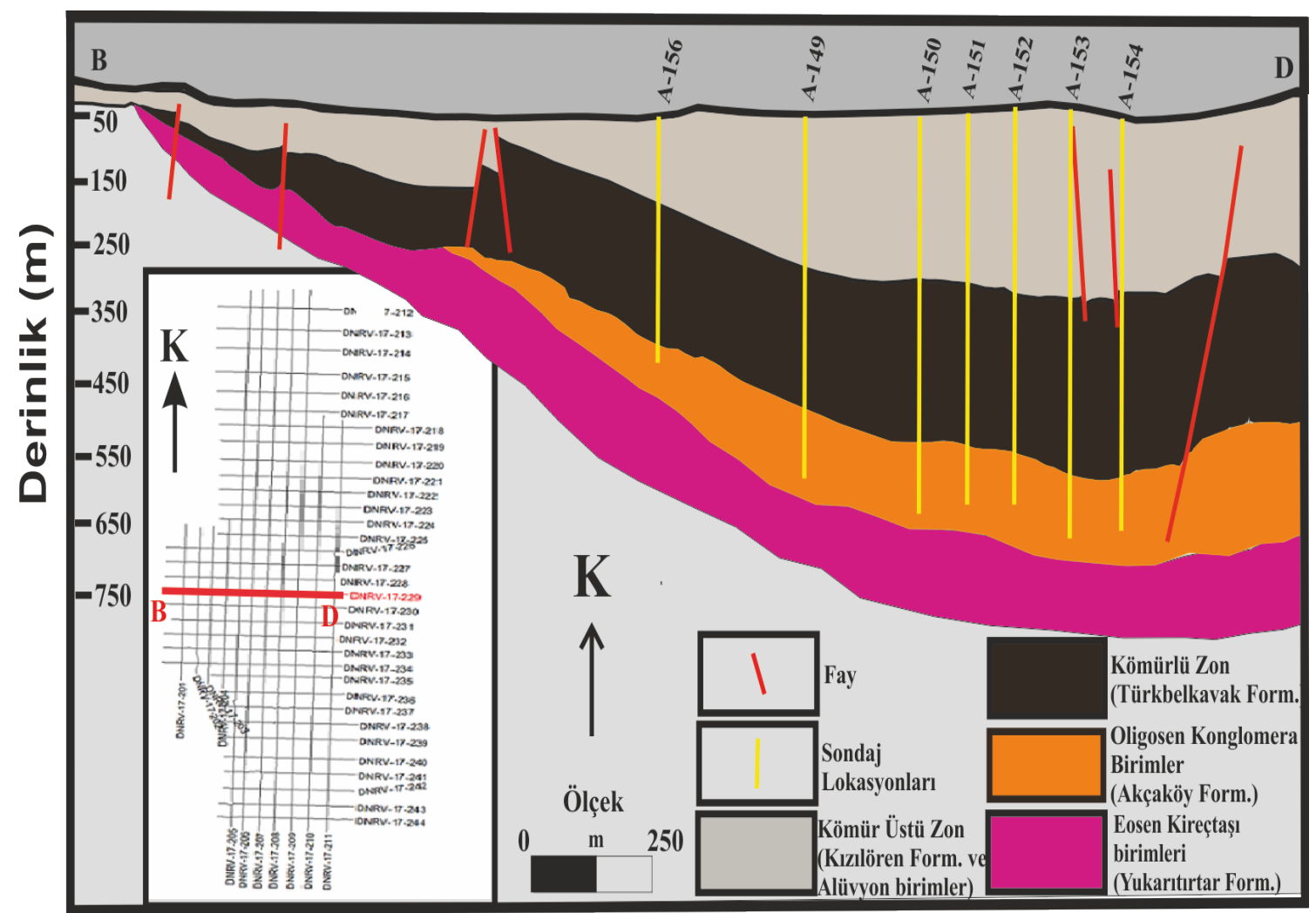

Şekil 8. Çalışma alanındaki DNR-17-229 nolu sismik hattan derlenmiş K-G uzanımlı jeolojik enine kesit ([7]'den değiştirilerek) 


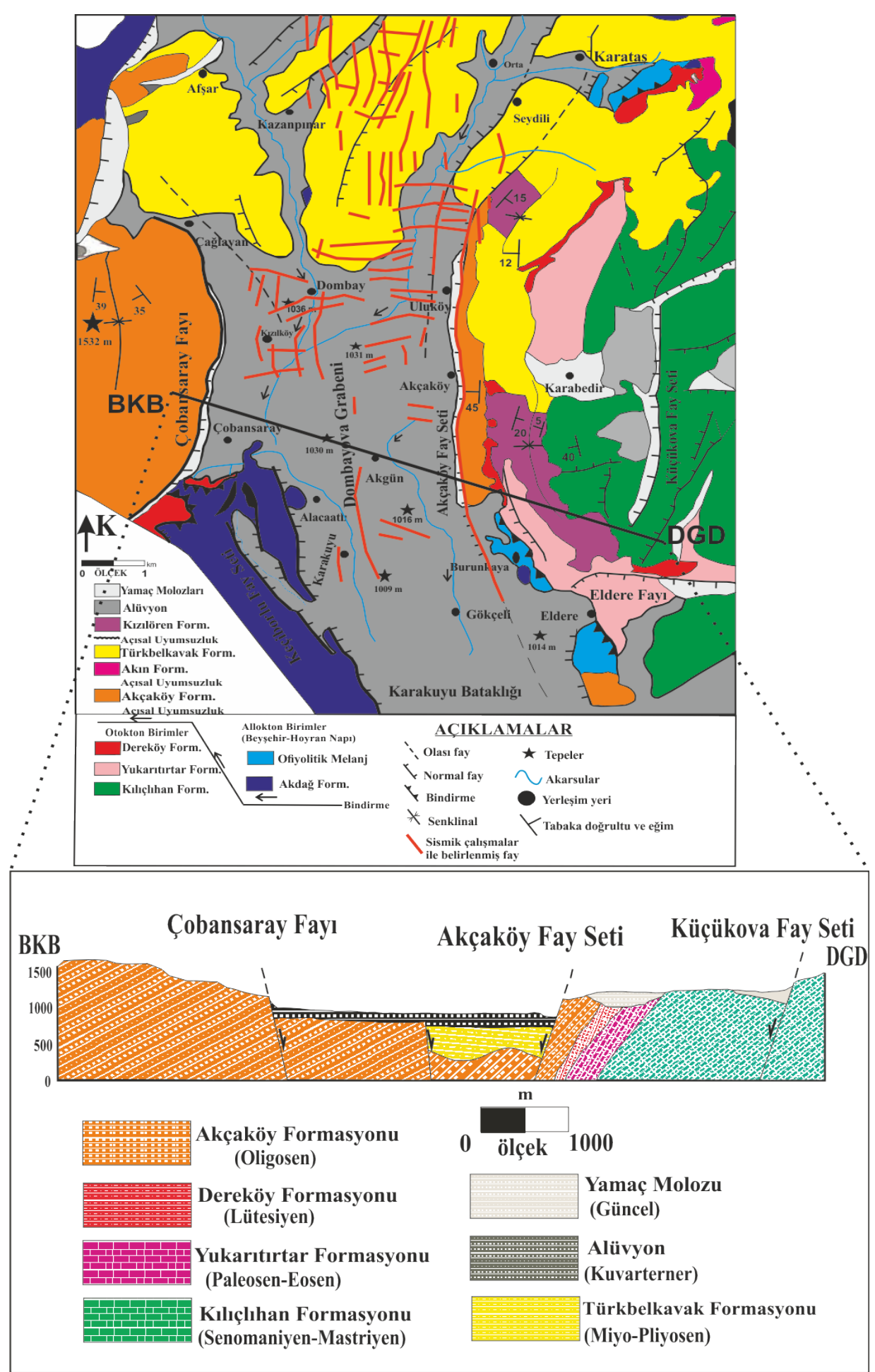

Şekil 9. Çalışma alanının Jeolojik haritası ile BKB-DGD yönlü jeolojik enine kesiti 
Afyonkarahisar-Dinar Dombayova Kömür Sahasının Tektono-stratigrafik Olarak İncelenmesi, Saha İçindeki Linyit Depolarının Jeolojik Gelişimi ve Rezerv Olanakları

\section{2. Çalışma Sahasındaki Kömürlerin Jeolojik Konumu ve Özellikleri}

Çalışma bölgesindeki linyitler genellikle kalınlığg birkaç cm'den birkaç 10 m'ye kadar değişkenlik gösteren paralel bantlar halinde oluşmuşlardır. Ayrıca linyitlerin altında ve üstünde veya her iki kömür damarı arasında silttaşı, kiltaşı, kumtaşı, marn gibi ince taneli sedimanlar bulunmaktadır. Dombayova kömür havzasında kömür damarları, grabenin orta kısımlarında kalın olup, havza kenarlarına doğru incelerek son bulmaktadır. Graben havzasındaki linyitler genellikle koyu kahve, siyah renkli olup ağırlıklı olarak gölsel ortam sedimanları olan marn ve kiltaşını üzerler ve yine marn ve kiltaşları tarafından üzerlenmektedirler. $\mathrm{Bu}$ tabakalar genellikle organik boyamalı ve bol gastropod fosilleri içermektedir (Şekil 11). Yapılan sondaj çalışmaları sonucunda havzada kömürlü seviyelere giriş ortalama olarak 280 metre olarak tespit edilmiștir. Ortalama kömürlü zon çıkış metrajı ise 499 metre olarak belirlenmiştir. Sahadaki ortalama kömür kalınlığı ise 45,20 metre olarak tespit edilmiştir. Kömürleşme havzasında tabakalar, bölgedeki tektonik süreçler nedeni ile $10^{\circ}-30^{\circ}$ arasında değişen eğimlenmelere maruz kalmışlardır (Şekil 10) [5].
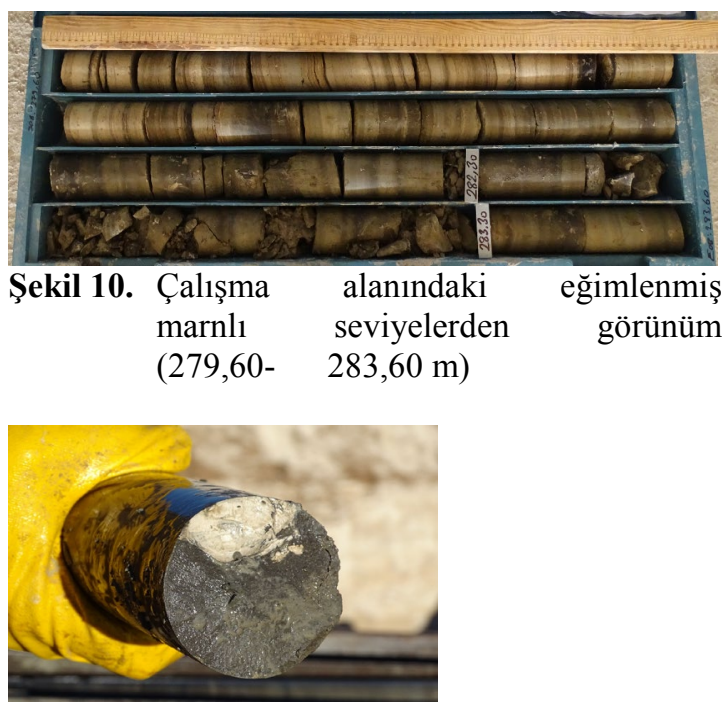

Şekil 11. Linyitli seviyeler arasındaki kırıntılı birimlerde gözlenen Gastropod fosillerinin görünümü

\subsection{Jeofizik Çalışmalar}

Dombayova kömür sahasında, kuyu logu jeofizik çalışmalar kapsamında "gamma-ray, nötron ve density" jeofizik çalışmaları yapılmışken (Şekil 12a), yüzey jeofizik çalışmaları kapsamında ise sismik yansıma modeli kullanılarak sismik çalışmalar yapılmıştır (Şekil 12b). Sismik çalışmalar ile tektonizma ve bunun sonucunda oluşan fayların uzanımlarının belirlenmesi ve bölgenin tektonik yönden yorumlanmas1 sağlanmıştır. Bu kapsamda kömür madenciliği çalışmalarında faylanmalar sonucunda oluşması muhtemel tehlikelerin öngörülmesi ve olas1 kazaların minimum hale getirilmesi amaçlanmıştır. Kuyu jeofiziği çalışmaları kapsamında; linyitli birimler, radyoaktivite, yoğunluk ve gözeneklilik özelliklerine göre gamma-ray, density ve nötron log çalışmaları yapılarak diğer birimlerden ayrılmıştır. A-306 nolu sondajda kömürlü birimler genel olarak düşük radyoaktivite, düşük yoğunluk ve yüksek gözeneklilik özelliklerine sahiptirler (Şekil 12a). Bu nedenle; kömürlü birimlerde diğer birimlere nazaran gamma-ray ve density log değerleri yüksek, nötron log değeri ise düşük çıkmaktadır. Çünkü sondadan gönderilen 1şınlar kayaçlarda yüksek tepkimeye neden oluyorsa değerler düşük okunmakta, düşük tepkimeye neden oluyorsa değerler yüksek okunmaktadır. Böylece radyoaktivite, yoğunluk ve gözeneklilik değerlerinin hep beraber değerlendirilmesi suretiyle kömürlü seviyeler ve diğer seviyelerin birbirlerinden ayırt edilmesi sağlanmıştır. $\mathrm{Bu}$ ölçümler jeolojik loglarla da karşılaştırılıp, kömürlü birimler ile diğer birimlerin en doğru şekilde tespit edilmesi sağlanmıştır. Ayrıca Şekil 12b' de sismik çalıșmalar ile desteklenmiş yaklaşık 6 km uzunluğundaki kuzey-güney yönlü jeolojik enine kesitte, kömürlerin basamak şeklinde derinleşmesine neden olan doğu-batı uzanımlı normal fay özellikli birçok ikincil fay belirlenmiştir. Birbirine yakın sondajların kömür giriş-çıkış seviyelerindeki farklar da bahse konu fayların varlığını kanıtlar niteliktedir.

\subsection{Rezerv Geliştirme Sondajları}

İnceleme alanında 231 adet rezerv geliştirme 22 adet jeoteknik amaçlı toplam 255 adet sondaj 


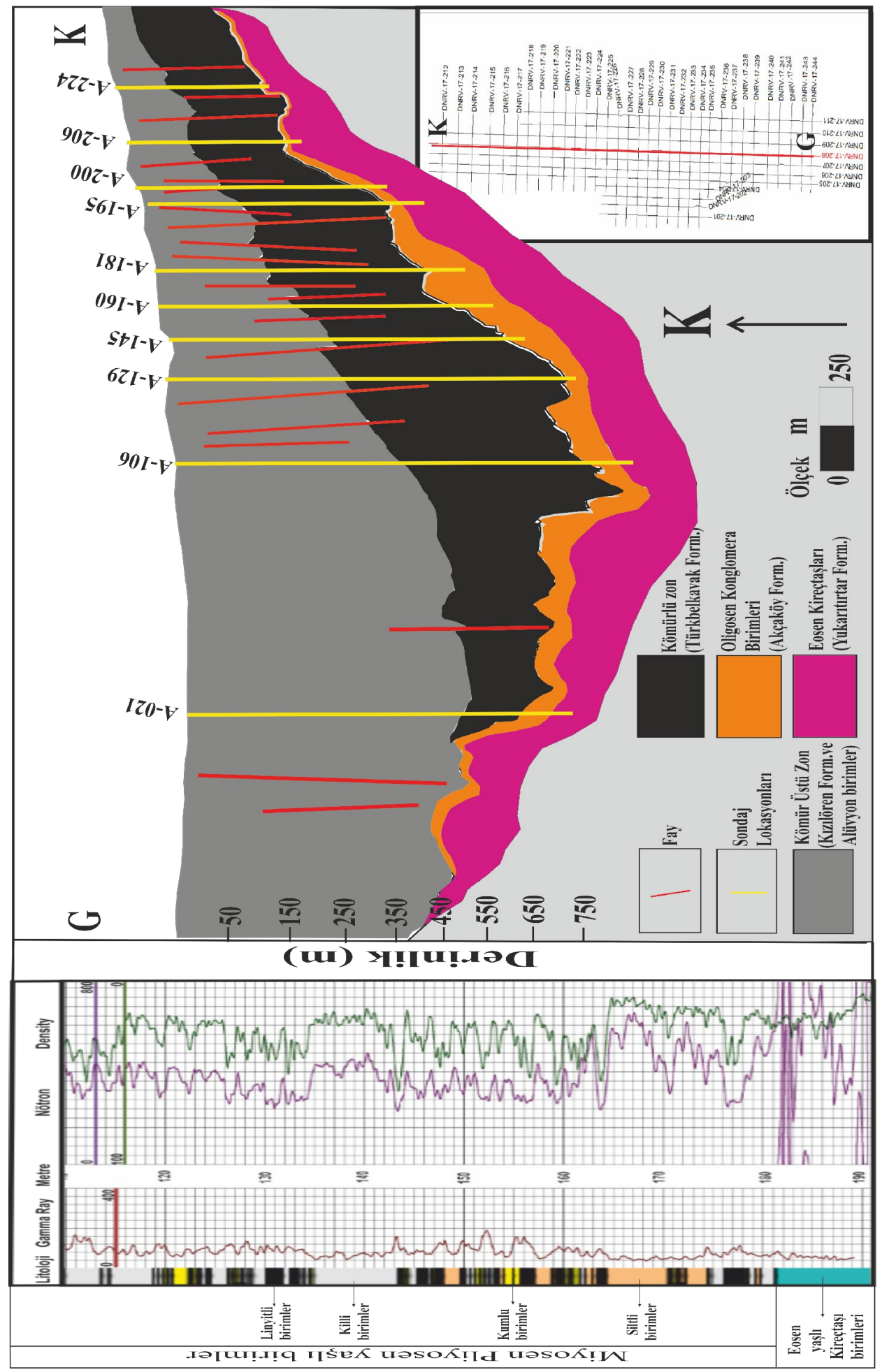

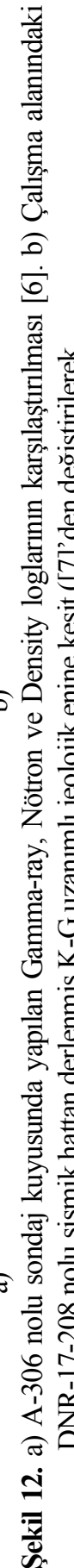


yapılmış ve bu sondaj çalışmaları neticesinde toplamda yaklaşık olarak 140 bin metre derinliğe ulaşılmıştır. Sondajlar, linyitli seviyeler (Şekil 14) geçildikten sonra temel birimler olarak kabul edilen, havzasının orta kisımlarında genellikle Miyo-Pliyosen yaşlı karasal kırmızı renkli çamurtaşı birimlerinde (Şekil 15), havzanın orta ve doğu kısımlarındaki bazı sondajlarda Oligosen yaşlı konglomeralarda (Şekil 16), havzanın kuzey ve batı kenar kesimlerinde yapılan birçok sondajda ise Eosen yaşlı kireçtaşı birimlerine ulaşıldığında sonlandırılmıştır (Şekil 17).

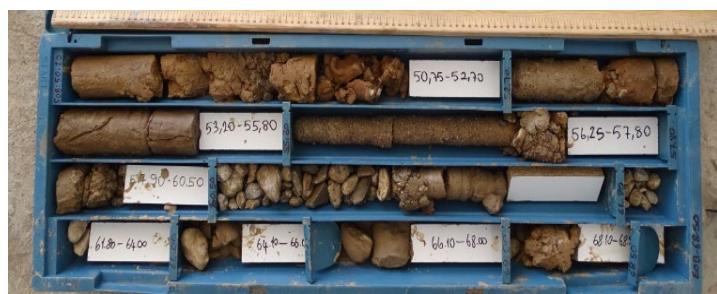

Şekil 13. Grabenin orta kesimlerinde yüzeylenen çakıllı-kumlu ve killi birimlerde kesilmiş olan karotların yakından görünümü $(50,20-68,50 \mathrm{~m})$

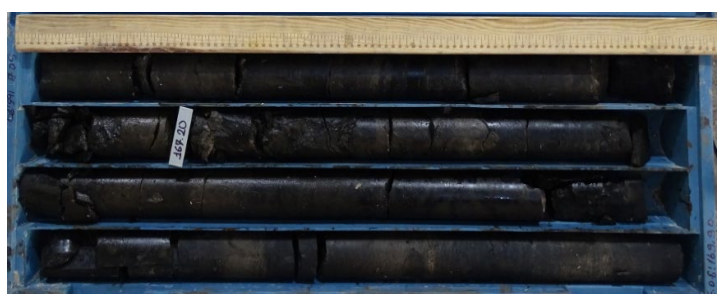

Şekil 14. Kömürlü birimleri içeren Miyo-Pliyosen yaşl1 Güzelyayla formasyonuna ait karotların genel görünümü (166-170 m)

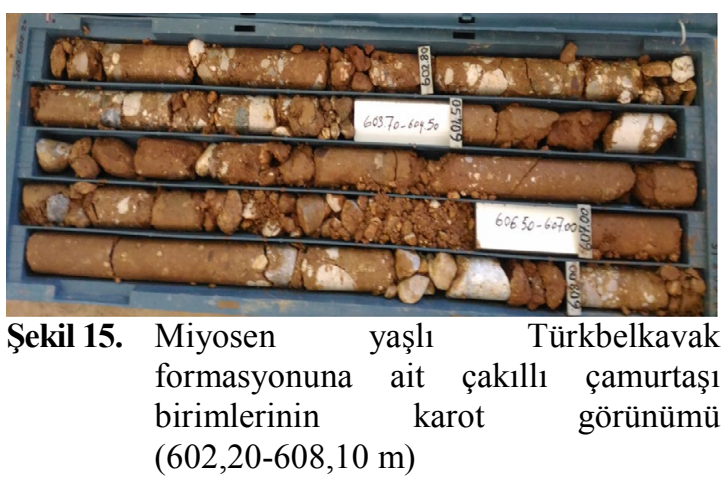

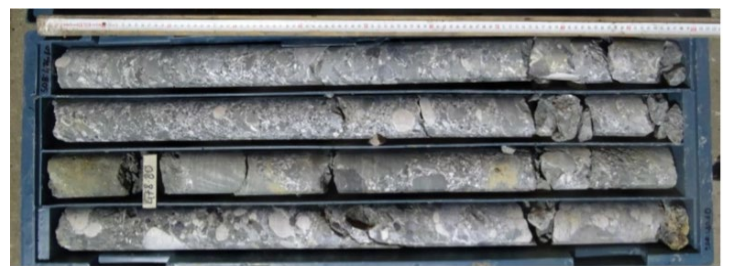

Şekil 16. Oligosen yaşlı konglomeratik birimlerin (Akçaköy form.) karot örneklerinin görünümü $(476,60-480,60 \mathrm{~m})$

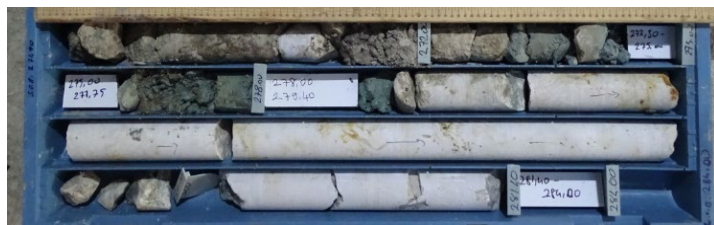

Şekil 17. Eoesen yaşlı Yukarıtırtar formasyonuna ait kireçtaşı birimlerinden görünüm (271,90-284 m)

\section{5. Çalışma Alanındaki Linyitlerin Kimyasal Özellikleri}

Sahada kimyasal analiz çalışmaları kapsamında nem, kül, sabit karbon, uçucu madde değerlerinin belirlendiği kısa analiz çalışmaları ve $\mathrm{C}, \mathrm{H}, \mathrm{O}, \mathrm{N}$, $\mathrm{S}$ gibi elemenlerin belirlendiği elementer analiz çalışmaları yapıllmıştır.

Yapılan sondaj çalışmaları ile havzanın derinliğinin kuzeybatıdan güneydoğuya doğru artmakta olduğu tespit edilmiştir. Sıcaklık, zaman, derinlik ve gömülmeyle orantılı olarak söz konusu bölgelerde diğer bölgelere nazaran kömürleşme derecesi daha fazla olmuştur. Buna bahisle havzanın doğu ve güneydoğu kesimlerinde bulunan linyitlerin alt 1s1l değerleri kömürleşmeyle orantılı olarak artmaktadır. Havzanın bu bölgelerinde sabit karbon ve uçucu madde oranlarının yüksek olduğu, nem ve kül değerlerinin ise daha düşük olduğu görülmektedir. Yapılan kimyasal analiz çalışmaları ile havza içerisindeki linyitlerin ortalama nem değeri $\% 40,57$, kül değeri $\% 18,97$, uçucu madde $\% 27,65$, sabit karbon değeri $\% 12,81$, külde kükürt \%0,73, toplam kükürt \%1,25 ve alt $1 \mathrm{~s} 1 \mathrm{l}$ değer ise $1783 \mathrm{kcal} / \mathrm{kg}$ olup (Şekil 21) karbon \%19,42, hidrojen \%1,16, azot \%0,61, oksijen değeri \%12,97 olarak tespit edilmiştir [6]. 


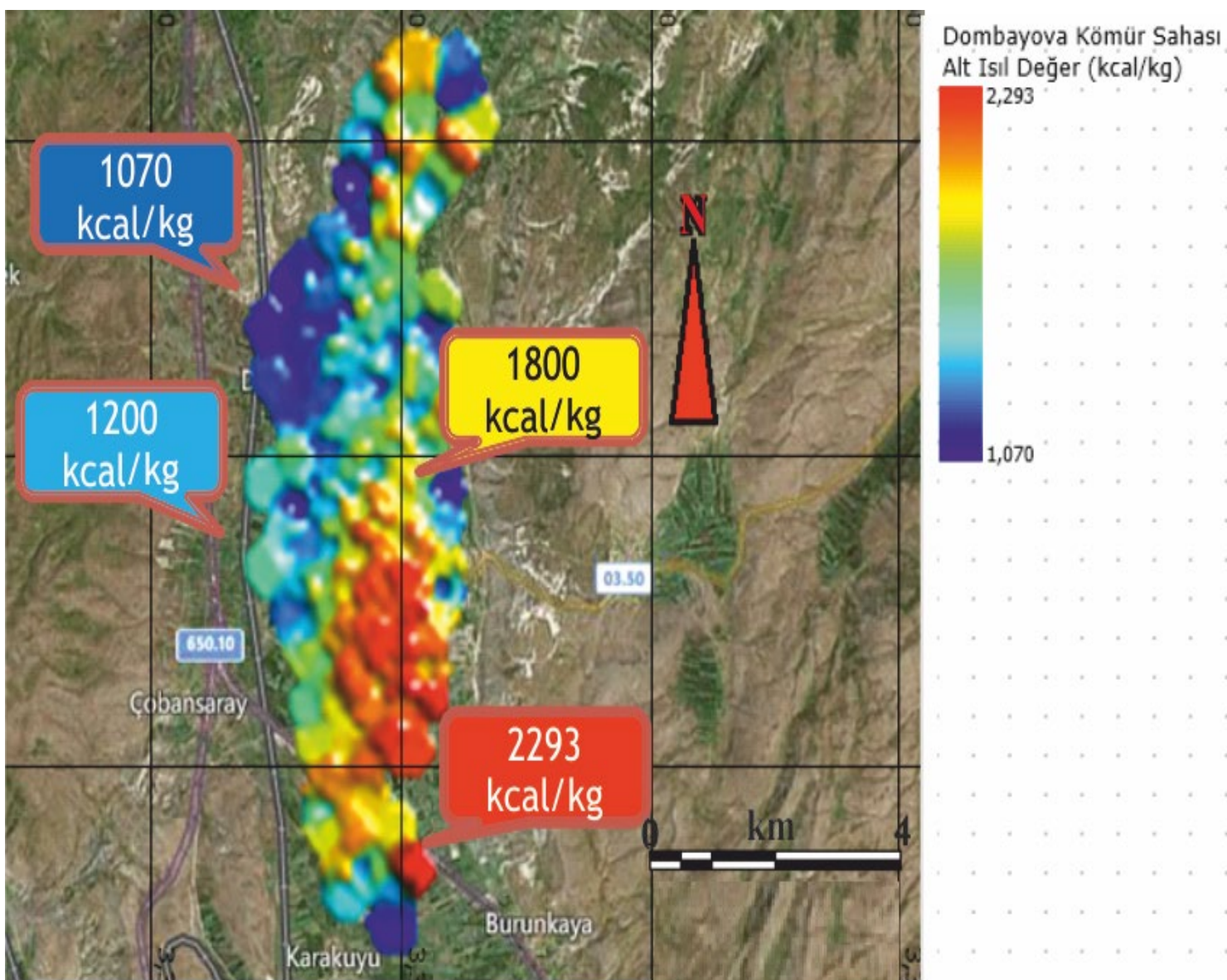

Şekil 18. Dombayova kömür sahasındaki linyitlerin alt ısıl değerleri

\section{6. İnceleme Alanı Kömürlerin Korelasyonu ve Rezerv Olanakları}

Dombayova kömür havzasından alınan sondaj litoloji logları, sondaj lokasyon haritası, sondajlardan geçen jeolojik kesitler ve üç boyutlu blok modelleri kullanılarak kömür tabakalarının korelasyonu yapılmıştır. Sondajlara ait litolojik bilgiler kullanılarak kabaca havzanın geometrisi ve yapısal unsurlarını gösteren üç boyutlu jeolojik blok modeli oluşturulmuştur (Şekil 19). Bahsedilen üç boyutlu modelleme işlemleri Mapinfo-Discover ve Netpromine programları ile yapılmıştır. Kömürler, seviyelerine ve kalınlıklarına göre damarlar haline getirilmiş ve bu damarlar birleştirilerek modelleme işlemi yapılmıştır. İlk aşamada yüzeyleri belirlenen damarlar birleștirilmiş, sonra katı modele dönüştürülmüş, bunun ardından $5 \mathrm{~m}$ derinliğinde ve $50 * 50 \mathrm{~m}$ düşey ve yatay uzunluklarda bloklara bölünerek üç boyutlu blok model işlemi yapılmıştır. Böylece kömürlerin havzada oluşum şekli ortaya konulmuş ve belirlenen bloklar ile havzanın rezerv potansiyeli hesaplanmıştır. Blok modelleme işlemi ile havza içerisindeki linyitlerin yaklaşık 1,525 milyar ton rezerve sahip olabileceği tespit edilmiştir [4].

Havza geometrisinin kuzey-güney yönünde geliştiği, havzanın merkezinden çevresine doğru sığlaştığı ve havzanın kenar kısımlarında linyit tabakalarının kalınlığının azaldığ 1 tespit edilmiştir (Şekil 19). Ayrıca havzanın temel topografyası belirlenmiş, kömür oluşumunun tektonik kontrollü 
geliştiği sonucuna ulaşılmıştır (Şekil 8, Şekil 12b). Çalışma alanındaki kömür rezervinin hesaplanmasında poligon yöntemi kullanılmıştır. Kömür rezerv hesabı yapılırken birbirine yakın sondajlardan üçgen elde edilmek suretiyle; bulunan her bir üçgenin alanının hesaplanması ve bulunan alanın kömür kalınlığ 1 ile kömür yoğunluğu değerleriyle çarpılması ile hesaplanmaktadır. Çalışma alanı 449 adet üçgene ayrılmış ve bu alanların toplamı 24814,896 $\mathrm{m}^{2}$ olarak hesaplanmıştır (Şekil 19). Sahadaki sondajların ortalama kömür kalınlığı ise 45,20 m olarak belirlenmiştir. Yapılan analizler neticesinde ise kömür yoğunluğu $1,36 \mathrm{ton} / \mathrm{m}^{3}$ 'dir. Tüm bu değerlerin çarpımı bize kömür rezervini vermektedir $\mathrm{ki}$ bu rakam yaklaşık olarak 1,525 milyar ton ( \pm 100 milyon $)$ olarak hesaplanmıştır [4].

\section{Dombayova Kömür Havzası}

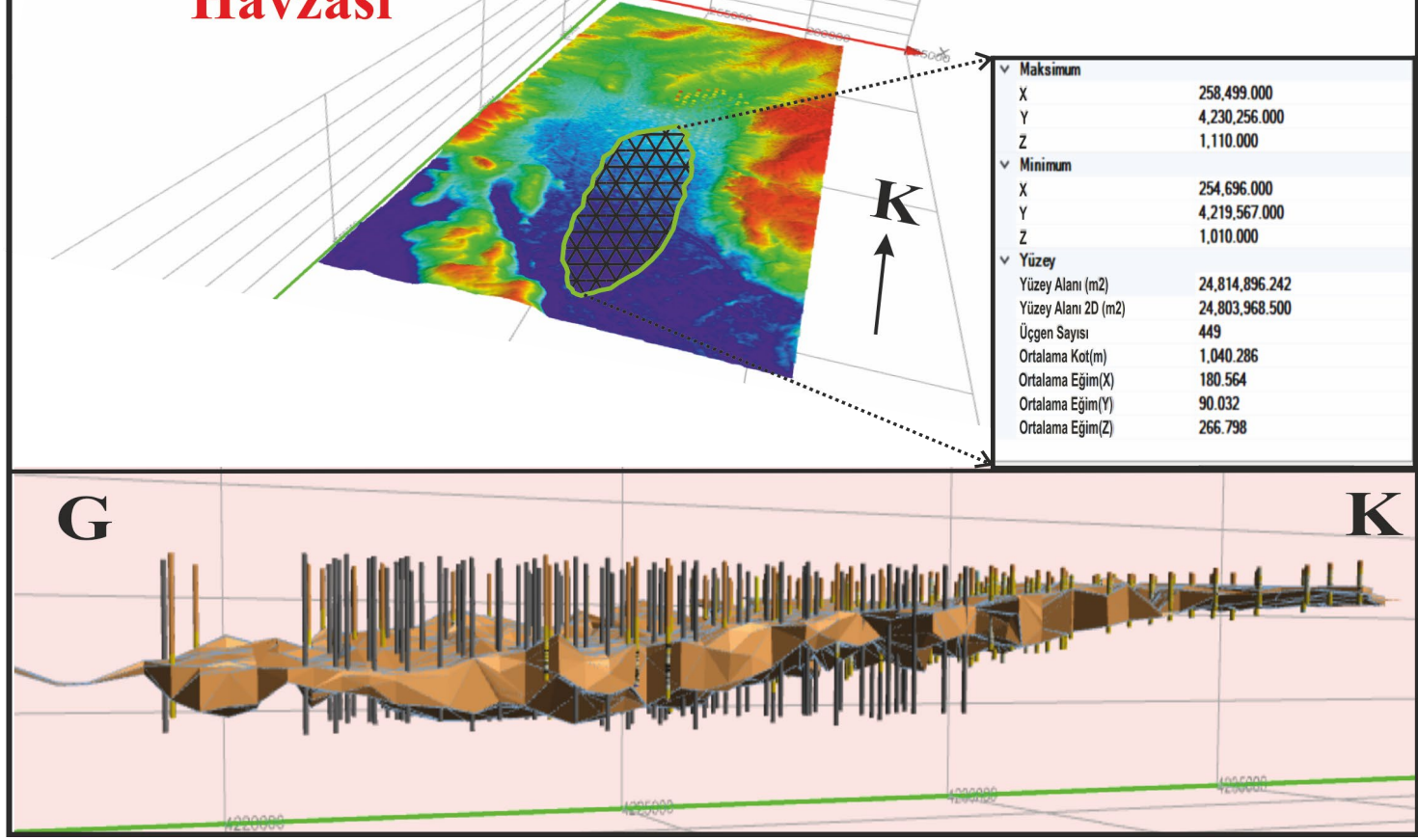

Şekil 19. Çalışma alanındaki linyitlerin rezerv hesap çalışmaları ve blok model işlemlerinden görünüm

\section{SONUÇLAR}

Dombayova grabeni içerisinde çökelmiş linyitlerin, jeolojik gelişimi ve yaklaşı rezerv miktarını tespit etmek amaciyla sahada rezerv geliştirme sondajları ve jeofizik çalışmalar yapılmıştır. Sondaj çalışmaları kapsamında toplam metrajı yaklaşık 140 bin metre olan 255 adet sondaj yapılmıştır. Jeofizik çalışmalar kapsamında ise sondajların bitmesinin hemen ardından kuyu jeofiziği (gamma-ray, nötron, density) çalışmaları ile kömürlü seviyelerin tespiti ve devamlılığ1, havza içerisindeki fayların analizleri için sismik çalışmalar (sismik yansıma modeli) yapılmıştır. Böylece havzanın jeolojik gelişimi ve havza içerisinde konumlanmış linyitlerin rezerv hesabı çalışmaları yapılmıştır. 
Yapılan çalıșmalar ile havzanın temel topografyası tespit edilmiş; havza geometrisinin kuzey-güney yönünde geliştiği, havzanın merkezinden çevresine doğru sığlaştığı ve kömür kalınlığının havza merkezinden havza kenarlarına doğru azaldığı tespit edilmiştir.

Sondaj çalışmaları ile Dombayova Kömür Havzasında ortalama kömür giriş seviyesi 280 metre olarak belirlenirken ortalama kömür çıkış seviyesi ise 499 metre olarak tespit edilmiştir. Havzadaki linyitlerin ortalama kalınlığı ise 45,20 metre olarak belirlenmiştir.

Sondajlardan elde edilen veriler Mapinfo Discover ve Netpromine programları ile derlenmiş ve havza içerisindeki toplam linyit rezervi yaklaşık olarak 1,525 milyar ton ( \pm 100 milyon) olarak hesaplanmıştır [4].

Çalışma alanının kuzey ve batı kesimlerinde konumlanmış linyitlerin; rezerv miktarı ve kalorifik değerleri (1070-1350 kcal/kg) düşükken nem değeri (\%45-\%50) yüksektir. Fakat havzanın merkez kısımlarındaki linyitlerin rezerv miktarı ve kömürleşmeyle orantılı olarak kalorifik değerleri $(1800-2300 \mathrm{kcal} / \mathrm{kg})$ havzanın diğer kesimlerine göre daha yüksek iken bu bölgelerde nem değerleri ise (\%32-\%40) düşük olarak gözlenmiştir.

Sondaj çalışmaları ile kömür varlığının kuyu jeofiziği ve sismik çalışmalar ile desteklenmesi, kömür korelasyonun oluşturulmasında ve sahadaki mevcut fay ve fay takımlarının varlığının tespiti açısından önemli bir husus olmuştur. Nitekim söz konusu faylardan dolayı sahada birbirine yakın sondajlar arasında, kömür seviyeleri farklılık göstermektedir. $\mathrm{Bu}$ farklılıkların yer yer 100 metreye yaklaşır olduğu gözlemlenmektedir. $\mathrm{Bu}$ durum da kömür oluşumunun tektonik kontrollü geliştiği sonucunu destekler niteliktedir. Sahanın yoğun tektonik aktiviteler neticesinde şekillenmiş olması ve buna koşut olarak gelişmiş olan fay ve fay takımlarının varlığı, geçmiş yıllarda meydana gelen tarihsel ve yıkıcı depremlerin meydana gelmiş olması ileride yapılması planlanan mühendislik çalışmaları ile ilgili önemli parametrelerdir. $\mathrm{Bu}$ gibi hususların gelecek dönemlerde yapılacak olan mühendislik çalışmalarına, yer seçimine ve malzeme kullanımı gibi özellikleri mevcut veriler 1şı̆̆ında değerlendirilmelidir.

\section{TEŞEKKÜR}

Bu çalışma, Çukurova Üniversitesi Bilimsel Araştırma Projelerince FYL-2018-10865 no'lu proje kapsamında desteklenmiştir. Çukurova Üniversitesi Bilimsel Araştırma Projeleri Koordinasyon Birimine, EÜAŞ Genel Müdürlüğü Maden Sahaları Daire Başkanlığına, Karapınar Maden Etüt Tesis Müdürlügüune, MTA Konya Bölge Müdürlüğünden Jeoloji Mühendisi Nurdoğan SERTEL'e, ve Çukurova Üniversitesi doktora öğrencisi Veli KESKİN'e katkılarından dolayı teşekkür ederiz.

\section{KAYNAKLAR}

1. www.mta.gov.tr/v3.0/arastirmalar/komur-aramaarastirmalari.

2. www.mta.gov.tr/v3.0/sayfalar/hizmetler/kutuph ane/ekonomi bultenleri/2013 16/35.pdf.

3. Koçyiğit, A., Cihan, M., Özacar, A., 2001. Dombayova ve Sandıklı (Afyon) Grabenlerinin Depremselliği ve Kenar Faylarının Kinematik Analizi, Tübitak Proje No: YDABÇAG 199Y007, Ankara. 107.

4. Pekkıyıc1, K., 2019. Afyonkarahisar-Dinar Dombayova Kömür Sahasının TektonoStratigrafik Olarak İncelenmesi, Saha İçindeki Linyit Depolarının Jeolojik Gelişimi ve Rezerv Olanakları.

5. Kırman, E., Bulut, Y., Çolakoğlu, S., Gülhan, M.M., 2013-a, Afyonkarahisar İli, Dinar İlçesi 200804884 Ruhsat No'lu Linyit Sahasının Buluculuk Talebine Esas Jeoloji ve Rezerv Raporu, MTA Rapor No 11632, Ankara. 34.

6. Besbelli, B., Gülhan, M.M., 2019. Afyonkarahisar-Dinar-Dombayova Kömür Havzası Jeoloji ve Kaynak Geliştirme Raporu. 307.

7. Selçuk, S., Yağcı, F.G., Boyacı, F.S., Çetin, E., 2018. Afyonkarahisar-Dinar 2B (EÜAŞ) Sismik Projesi Veri İşlem ve Yorum Raporu. Türkiye Petrolleri Proje No: VRM17_K2B0027, 123. 
Afyonkarahisar-Dinar Dombayova Kömür Sahasının Tektono-stratigrafik Olarak İncelenmesi, Saha İçindeki Linyit Depolarının Jeolojik Gelişimi ve Rezerv Olanakları

8. McKenzie, D.P., 1972. Active Tectonics of the Mediterranean Region. Geophysical Journal of the Royal Astronomical Society, 55, 217-245.

9. Arpat, E., Şaroğlu, F., 1972. Doğu Anadolu Fayı ile İlgili Bazı Gözlem ve Düşünceler. 44-45.

10. Ketin, İ., 1966. Anadolu'nun Tektonik Birlikleri. MTA Derg., Ankara, 66, 23-34.

11. Ketin, İ., 1968. Türkiye'nin Genel Tektonik Durumu ile Başlica Deprem Bölgeleri Arasındaki İlişkiler. MTAD, 71, 129-134.

12. Şengör, A.M.C., $1980 . \quad$ Türkiye'nin Neotektoniğinin Esasları. Türkiye Jeol. Kür. Kon. Ser, No: 2, 40.

13. Şengör, A.M.C., Görür, N., Şaroğlu, F., 1985. Strike-slip Faulting and Related Basin Formation in Zones of Tectonic Escape: Turkey as a Case Study: in Biddle, K.T. and Christie-Blick, N., edts, Strike-slip Deformation, Basin Formation, and Sedimentation, Soc. Econ. Paleont. Min. Spec. Pub. 37 (in honor of J.C. Crowell), 227-264.

14. Dewey, J.F., Şengör, A.M.C., 1979. Aegean and Surrounding Regions: Complex Multiple and Continuum Tectonics in a Convergent Zone. Geological Society of American Bulletin. 90, 84-92.

15. Koçyiğit, A., 1984. Güneybatı Türkiye ve Yakın Dolayında Levha İçi Yeni Tektonik Gelişmeler, Türkiye Jeol.Kur. Bülteni. 27, $1-16$.

16. Öztürk, M.E., 1988. Balçıkhisar Karadilli Afyon Dereköy Isparta Dolayının Jeolojisi. MTA Genel Müdürlüğü Rapor No: 8946 (yayınlanmamış). 